\title{
PERANAN KEJAKSAAN TINGGI DALAM PENCEGAHAN TINDAK PIDANA KORUPSI DI KALIMANTAN TIMUR
}

\author{
Hudali Mukti dan Ayu Linanda \\ hudalimuktiuwgm@gmail.com, ayulinandahamsyah@gmail.com \\ Fakultas Hukum \\ Program Studi Ilmu Hukum \\ Universitas Widya Gama Mahakam Samarinda
}

\begin{abstract}
ABSTRAK
Kalimantan Timur tidak dapat terlepas dari sorotan pencegahan dan sekaligus pemberantasan tindak pidana korupsi. Hal ini karena kesempatan yang ada pada Kalimantan Timur lebih terbuka lebar. Banyaknya orientasi bidang sumber daya alam yang lebih di Kalimantan Timur ternyata menjadi objek sasaran yang manis untuk pelaku koruptor, jika tidak ada pengawasan dan pencegahan secara intensif sebelumnya oleh stakeholder terkait. Disinilah peranan Kejaksaan Tinggi di Kalimantan Timur ditantang bukan hanya menegakkan hukumnya tetapi juga mewujudkan pencegahan terjadinya tindak pidana korupsi yang terjadi di Kalimantan Timur. Penelitian ini bertujuan mengetahui dan mengkaji upaya Kejaksaan Tinggi Kalimantan Timur serta kendala yang dihadapi dalam mencegah tindak pidana korupsi.

Dalam penelitian ini menggunakan Teknik Purposive Sampling. Teknik pengumpulan data adalah observasi, wawancara mendalam dan dokumentasi. Jenis data adalah jenis primer dan skunder dengan analisis data adalah kualitatif.

Hasil yang dicapai dalam penelitian ini adanya gambaran peranan Kejaksaan Tinggi dalam melaksanakan upaya-upaya dalam pencegahan dan pemberantasan korupsi sehingga tercipta masyarakat yang kondusif, aman, dan nyaman yang jauh dari tindak pidana korupsi.
\end{abstract}

Kata kunci: Kejaksaan Tinggi Kalimantan Timur, pencegahan, tindak pidana korupsi.

\begin{abstract}
East Kalimantan cannot be detached from the spotlight of the prevention and eradication of criminal acts of corruption. This is because of the opportunity that exists in East Kalimantan is more wide open. The number of orientation field a more natural resources in East Kalimantan turns out to be a sweet target object for the perpetrators of the corruptor, if no supervision and intensive prevention beforehand by the stakeholders concerned. This is where the role of the Prosecutor in East Kalimantan are challenged not only to uphold the law but also embodies the prevention of the occurrence of the crime of corruption that occur in East Kalimantan. This research aims to find out and assess the efforts of Prosecutor of East Kalimantan as well as obstacles faced in preventing criminal acts of corruption.

In this study using a Purposive Sampling Technique. The technique of data collection is the observation, in-depth interviews and documentation. The data type is the type of primer and skunder with data analysis is qualitative.

Results achieved in this study the existence of the description of the role of the Prosecutor in carrying out efforts in the prevention and eradication of corruption so that created a conducive society, secure, and comfortable away from the criminal acts of corruption.
\end{abstract}

\section{Keywords: High Prosecutor's Office Kalimantan Timur, Corruption Prevention.}




\section{PENDAHULUAN}

\section{A. Latar Belakang}

Perbuatan tindak pidana korupsi layaknya seperti virus yang menggerogoti suatu bangsa, oleh karenanya perlu segera diberantas, karena apabila tidak ditindaklanjuti maka korupsi dapat menghancurkan apa saja yang melekat didalamnya. Indonesia adalah salah satu negara yang tengah menghadapi ini. Sebagai negara hukum (rechstaat), seperti yang termuat dalam batang tubuh UUD RI 1945, tepatnya pada Pasal 1 ayat (3), berbunyi: "Negara Indonesia adalah negara hukum", maka Indonesia wajib melindungi kesehjateraan rakyatnya dari tindak pidana korupsi sebagai kejahatan extra ordinary crime.

Kategori kejahatan extra ordinary crime yang melekat pada tindak pidana korupsi dapat terlihat dari dampak massif korupsi yang telah dirasakan oleh bangsa ini yaitu sulitnya memberantas kemiskinan, dan banyak masyarakat yang sulit mengakses fasilitas umum, hingga harga barang dan jasa yang terus meningkat. Bukan hanya itu, maraknya angka tindak pidana korupsi di Indonesia mempengaruhi fluktuasi kriminalitas kejahatan ditengah masyarakat, sehingga melahirkan pada pemerintah yang berakibat masyarakat melangkahi hukum dengan mengambil tindakan anarkis sebagai bentuk penghakiman kepada si pelaku tanpa memberikan kesempatan kepada pelaku. Dampak massif inilah yang menjadi kewajiban semua pihak untuk diperhatikan.

Kewajiban ini tidak hanya dilakukan oleh lembaga Komisi Pemberantasan Korupsi (KPK) yang bersifat independen memang telah diamanatkan dalam UndangUndang No 31 Tahun 1999 tentang Pemberantasan Tindak Pidana Korupsi sebagaimana telah diubah menjadi UndangUndang Nomor 20 Tahun 2001 tentang Pemberantasan Tindak Pidana Korupsi, namun juga menjadi kewajiban yang dilakukan oleh seluruh stakeholder terkait, baik lembaga penegak hukum, maupun masyarakat dalam memberantas tindak pidana korupsi.
Oleh karena itu perlu adanya kerjasama yang bersinergi antar KPK, lembaga penegak hukum, serta masyarakat agar dapat terlibat dalam pemberantasan tindak pidana korupsi. Salah satu lembaga penegak hukum yang ikut berperan dalam pemberantasan tindak pidana korupsi, adalah Kejaksaan. Dalam Undang-Undang Nomor 16 Tahun 2004 tentang Kejaksaan Republik Indonesia Kejaksaan memiliki mandat dalam bidang penuntutan. Oleh karenanya dalam hal ini Kejaksaan memiliki peranan penting dalam pemberantasan tindak pidana korupsi.

Dalam hal pemberantasan tindak pidana korupsi, tentu tidak cukup hanya dilakukan dari sisi penindakan, namun juga perlu dilakukan dari sisi pencegahan. Oleh karenanya, Kejaksaan juga ikut memprioritaskan pemberantasan tindak pidana korupsi melalui bidang pencegahan. Hal ini yang kemudian diterapkan oleh Kejaksaan yang tersebar di seluruh pelosok daerah di Indonesia.

Salah satunya Kejaksaan Tinggi Kalimantan Timur yang berkomitmen dalam pemberantasan tindak pidana korupsi khususnya daerah Kalimantan Timur, karena tindak pidana korupsi merupakan kejahatan yang dilakukan bukan hanya mengenai nominal kerugian negara saja, namun juga mengenai subjek tindak pidana korupsi yang dapat dilakukan di mana saja. Makna kata "dimana saja" tersebut memiliki maksud bahwa tindak pidana korupsi juga ditemukan di setiap daerah di Indonesia, sehingga bukan hanya terjadi dipusat saja.

Oleh karenanya, Kalimantan Timur juga tidak terlepas dari bayang-bayang perbuatan tindak pidana korupsi ini. Bukan tidak mungkin Kalimantan Timur yang merupakan salah satu provinsi terluas di Indonesia dapat luput dari jeratan tindak pidana korupsi. Faktanya, Kalimantan Timur menjadi salah satu daerah yang menjadi ladang emas bagi para koruptor khususnya pada bidang sumber daya alam, mulai dari pertambangan, minyak, dan gas bumi, serta kelapa sawit dan berakibat rusaknya lingkungan yang dirasakan langsung oleh masyarakat Kalimantan Timur. 
Ini menjadi faktor utama yang membuat daerah Kalimantan Timur menjadi sorotan dalam pemberantasan tindak pidana korupsi yang harus segera disikapi oleh stakeholder terkait. Sikap tersebut kemudian diimplementasikan oleh Kejaksaan Tinggi Kalimnatan Timur dengan menjadikan daerah Kalimantan Timur sebagai prioritas dalam pemberantasan tindak pidana korupsi.

Implementasi tersebut diwujudkan dalam sebuah program kerja yang solid sebagai bentuk komitmen dalam memberantas tindak pidana korupsi yang selaras dengan gambaran visi misi Kejaksaan agar dapat menekan angka kriminalitas tindak pidana korupsi khususnya yang terjadi di seluruh pelosok daerah Kalimantan Timur.

Dalam hal mencapai tujuan menekan angka kriminalitas tindak pidana korupsi yang terjadi di seluruh pelosok daerah Kalimantan Timur, Kejaksaan Tinggi Kalimantan Timur menyadari tidak cukup hanya melalui penindakan, sehingga diperlukan upaya lain dalam memberantas tindak pidana korupsi. Upaya lain tersebut yang kemudian dilakukan bersama-sama oleh Kejaksaan Tinggi Kalimantan Timur dengan stakeholder yang lain, seperti Komisi Pemberantasan Korupsi (KPK), maupun masyarakat.

Upaya tersebut ialah dengan mengefektifkan fungsi pencegahan korupsi dengan tujuan untuk mendorong masyarakat yang bebas korupsi, namun sejauh ini, pandangan masyarakat terhadap peranan Kejaksaan Tinggi Kalimantan Timur dalam bidang penindakan terhadap tindak pidana korupsi memiliki hasil yang baik, sedangkan upaya Kejaksaan Tinggi Kalimantan Timur dalam mengimplementasikan fungsi pencegahan tindak pidana korupsi tersebut belum mendapatkan hasil yang optimal untuk dapat dirasakan masyarakat secara langsung.

Oleh karenanya dalam tulisan ini penulis menganalisa permasalahan tersebut secara konkrit, dan lugas yang dituang dalam tulisan "Peranan Kejaksaan Tinggi Dalam Pencegahan Tindak Pidana Korupsi Di Kalimantan Timur".

\section{B. Permasalahan}

Berdasarkan uraian dalam latar belakang, maka yang menjadi rumusan masalah dalam penulisan ini adalah sebagai berikut :

1. Apa saja upaya Kejaksaan Tinggi Kalimantan Timur dalam mencegah tindak pidana korupsi di Kalimantan Timur?

2. Bagaimana kendala-kendala yang dihadapi dalam mewujudkan upaya Kejaksaan Tinggi Kalimantan Timur untuk mencegah terjadinya tindak pidana korupsi di Kalimantan Timur?

\section{Tujuan dan Manfaat Penelitian}

Adapun Tujuan Penelitian ini untuk mengetahui dan mengkaji upaya Kejaksaan Tinggi Kalimantan Timur dalam mencegah tindak pidana korupsi yang terjadi di Kalimantan Timur, dan untuk mengetahui dan mengkaji kendala-kendala yang dihadapi dalam mewujudkan upaya Kejaksaan Tinggi Kalimantan Timur untuk mencegah terjadinya tindak pidana korupsi di Kalimantan Timur. adalah:

Adapun Manfaat Penelitian ini

1. Akademisi

Sebagai bahan kajian dan menambah khasanah didalam perkembangan ilmu hukum bagi akademisi.

2. Pemerintah

bahan masukan bagi pemerintah dalam mencegah dan memberantas terjadinya tindak pidana korupsi di Kalimantan Timur.

\section{METODE PENELITIAN}

Penelitian ini menggunakan penelitian yuridis empiris. ini menggunakan data sekunder dan data primer. Pada data sekunder digunakan dalam penelitian ini yang diperoleh dari bahan hukum primer dan bahan hukum sekunder serta bahan hukum tersier. ${ }^{1}$ Bahan hukum primer terdiri dari Undang-Undang

1 Amiruddin dan Zainal Asikin, 2004, Pengantar Metode Penelitian Hukum, Jakarta, PT. Raja Grafindo Persada., Hlm., 30-31. 
Dasar Negara Republik Indonesia Tahun 1945, Undang-Undang Nomor 08 Tahun 1981 tentang Hukum Acara Pidana (KUHAP), Undang-Undang No 31 tahun 1999 tentang Pemberantasan Tindak Pidana Korupsi sebagaimana telah diubah dengan Undang-Undang Nomor 20 Tahun 2001, Undang-Undang Nomor 30 Tahun 2002 tentang Komisi Pemberantasan Tindak Pidana Korupsi, Undang-Undang Nomor 16 Tahun 2004 tentang Kejaksaan Republik Indonesia.

Bahan hukum sekunder berupa Buku tentang tindak pidana korupsi, naskah akademik, hasil penelitian, tesis, jurnal, internet dan surat kabar. Bahan hukum tersier berupa kamus hukum, dan kamus besar bahasa Indonesia. Data primer diperoleh dari para stakeholder terkait dengan permasalahan yang diteliti dengan metode wawancara yaitu Kejaksaan Tinggi KalimantanTimur.

Teknik Pengumpulan data dalam penelitian ini peneliti menggunakan teknik Purposive Sampling.

Analisis data yang dilakukan berupa analisis data secara kualitatif yang bersifat deskriptif.

\section{PEMBAHASAN}

\section{A. Upaya Kejaksaan Tinggi \\ Kalimantan Timur Terhadap Pencegahan Tindak Pidana Korupsi di Kalimantan Timur}

Kejaksaan Tinggi Kalimantan Timur memiliki integritas moral yang tinggi serta kredibilitas, dan kapabilitas dalam melaksanakan tanggung jawab untuk menjalankan wewenang sebagai salah satu aparat penegak hukum terhadap perkara tindak pidana korupsi. Kejaksaan Tinggi Kalimantan Timur telah diberi amanat oleh Undang-Undang Nomor 16 Tahun 2004 tentang Kejaksaan Republik Indonesia untuk menjalankan kewenangan kekuasaan penuntutan pada setiap perkara pidana termasuk perkara tindak pidana korupsi. Oleh karenanya, Kejaksaan Tinggi Kalimantan Timur merupakan pion penting terhadap pemberantasan tindak pidana korupsi. Untuk itulah dalam menunjukkan keseriusan Kejaksaan Tinggi Kalimantan Timur pada keterlibatannya memberantas tindak pidana korupsi, bukan hanya berkomitmen dalam bidang penindakan namun juga berkomitmen terhadap bidang pencegahan.

Komitmen tersebut diwujudkan melalui peranan Kejaksaan Tinggi Kalimantan Timur yang telah diaplikasian dalam penyusunan berbagai bentuk program oleh Kejaksaan Tinggi Kalimantan Timur. Program pencegahan tersebut dapat penulis kemukakan sebagai berikut;

\section{Membentuk Tim Pengawal dan Pengaman Pemerintahan dan Pembangunan Pusat (TP4P), dan Tim Pengawal dan Pengaman Pemerintahan dan Pembangunan}

Dibentuknya Tim Pengawal dan Pengaman Pemerintahan dan Pembangunan Pusat (TP4P), dan Tim Pengawal dan Pengaman Pemerintahan dan Pembangunan Daerah (TP4D) merupakan gagasan teranyar yang dicetuskan lembaga Kejaksaan Republik Indonesia dalam rangka mewujudkan komitmen memberantas tindak pidana korupsi. Tujuan dibentuknya Tim Pengawal dan Pengaman Pemerintahan dan Pembangunan Pusat (TP4P), dan Tim Pengawal dan Pengaman Pemerintahan dan Pembangunan Daerah (TP4D) sendiri untuk mendampingi pemerintah dalam melakukan program pembangunan.

Sifat dari Tim Pengawal dan Pengaman Pemerintahan dan Pembangunan Pusat (TP4P), dan Tim Pengawal dan Pengaman Pemerintahan dan Pembangunan Daerah (TP4D) ini sendiri bersifat pengawasan. Oleh karenanya, secara garis besar tugas pokok, dan fungsi dari Tim Pengawal dan Pengaman Pemerintahan dan Pembangunan Pusat (TP4P), dan Tim Pengawal dan Pengaman Pemerintahan dan Pembangunan Daerah (TP4D), yaitu melakukan pengawasan terhadap penyerapan anggaran pemerintah.

Kedudukan Tim Pengawal dan Pengaman Pemerintahan dan Pembangunan Pusat (TP4P), dan Tim Pengawal dan 
Pengaman Pemerintahan dan Pembangunan Daerah (TP4D), berada di semua tingkatan. Untuk Tim Pengawal dan Pengaman Pemerintahan dan Pembangunan Pusat (TP4P) berkedudukan di Kejaksaan Agung, sedangkan Tim Pengawal dan Pengaman Pemerintahan dan Pembangunan Daerah (TP4D) berkedudukan di Kejaksaan Tinggi dan Kejaksaan Negeri.

Tim Pengawal dan Pengaman Pemerintahan dan Pembangunan Pusat (TP4P), dan Tim Pengawal dan Pengaman Pemerintahan dan Pembangunan Daerah (TP4D) sendiri merupakan Satuan Tugas (SATGAS) yang terdiri dari anggota bidang Intelijen, Pidana Khusus (Pidsus), serta Perdata, dan Tata Usaha Negara (Datun) yang berfokus pada upaya pencegahan.

Dalam hal pelaksanaan tugasnya, Tim Pengawal dan Pengaman Pemerintahan dan Pembangunan Pusat (TP4P), dan Tim Pengawal dan Pengaman Pemerintahan dan Pembangunan Daerah (TP4D) secara teknis melakukan pengawasan terhadap program pembangunan, perlu dilakukannya pendampingan pengawalan oleh Tim Pengawal dan Pengaman Pemerintahan dan Pembangunan Pusat (TP4P), dan Tim Pengawal dan Pengaman Pemerintahan dan Pembangunan Daerah (TP4D) terhadap semua kepala daerah dalam melaksanakan program pembangunan. Hasil pengawasan akan disampaikan dalam bentuk legal opinion kepada setiap kepala daerah selama proses kegiatan pembangunan berlangsung.

Tujuan teknis pengawasan dilakukan

oleh Tim Pengawal dan Pengaman Pemerintahan dan Pembangunan Pusat (TP4P), dan Tim Pengawal dan Pengaman Pemerintahan dan Pembangunan Daerah (TP4D) terhadap program pembangunan tersebut disebabkan karena Kejaksaan Tinggi Kalimantan Timur menemukan adanya penyalahgunaan kebijakan yang kerap kali dilakukan oleh aparatur birokrasi sebagai pengguna dan para pelaku usaha selalu penyedia barang dan jasa. Penyalahgunaan kebijakan inilah yang sering menimbulkan tindak pidana korupsi di Kalimantan Timur.

Dalam hal ini, penyebab penyalahgunaan kebijakan sering terjadi bukan hanya karena persetujuan kedua belah pihak, namun juga disebabkan karena adanya salah satu pihak atau dari pihak ketiga yang melakukan intervensi terhadap pengambilan keputusan terkait kebijakan yang diambil oleh aparat birokrasi, bahkan ditemukan terdapat intimidasi yang dilakukan oleh berbagai pihak terhadap aparat birokrasi yang dapat mempengaruhi kebijakan yang diambil terkait pelaksanaan program pembangunan.

Terjadinya penyalahgunaan kebijakan ini disebabkan adanya indikasi yang mempengaruhi hal tersebut terjadi, berupa stigma kriminalisasi kebijakan yang mempengaruhi aparatur birokrasi, dan para pelaku usaha, serta pihak-pihak terkait dalam pelaksanaan pengambilan kebijakan berbenturan dengan hukum yang ada, sehingga berdampak pada penyerapan anggaran yang rendah yang mengakibatkan pertumbuhan ekonomi menjadi lamban.

Oleh karena itulah, kehadiran Tim Pengawal dan Pengaman Pemerintahan dan Pembangunan Pusat (TP4P), dan Tim Pengawal dan Pengaman Pemerintahan dan Pembangunan Daerah (TP4D) berfokus pada upaya pencegahan tindak pidana korupsi terhadap program pembangunan melalui pemberian pengawalan dan pengamanan kepada aparatur birokrasi khususnya pejabat pemerintah atau setiap kepala daerah terkait akselerasi pembangunan dan program-program strategis pembangunan nasional.

\section{Pelaksanaan Supervisi serta Pemberian Dukungan Terhadap Lembaga Negara, Lembaga Pemerintah dan Non Pemerintah serta Lembaga Lainnya}

Dalam mewujudkan lembaga negara, lembaga pemerintah dan non pemerintah serta lembaga lainnya yang bebas korupsi, Kejaksaan Tinggi Kalimantan Timur memberikan dukungannya melalui pengarahan, dan pendampingan hukum saat melaksanakan program pembangunan sebagai pelaksanaan supervisi terhadap lembaga negara, lembaga pemerintah dan non pemerintah serta lembaga lainnya.

Pelaksanaan supervisi ini perlu dilakukan karena lembaga-lembaga tersebut diasumsi menjadi jalur masuknya tindak 
pidana korupsi di bidang birokrasi. Oleh karenanya keberadaan supervisi yang dilakukan oleh Tim Pengawal dan Pengaman Pemerintahan dan Pembangunan Pusat (TP4P), dan Tim Pengawal dan Pengaman Pemerintahan dan Pembangunan Daerah (TP4D) merupakan upaya represif dalam mewujudkan peranan Kejaksaan Tinggi Kalimantan Timur mencegah tindak pidana korupsi di Kalimantan Timur.

\section{Melakukan Kerjasama dan Koordinasi Dengan Lembaga- Lembaga Lainnya}

Dalam melaksanakan peranannya Kejaksaan Tinggi Kalimantan Timur tentu membutuhkan kolaborasi yang selaras dan saling besinergi dengan stakeholder lainnya. Oleh karenanya, kerjasama dan koordinasi merupakan titik utama dalam pencegahan tindak pidana korupsi yang dilakukan oleh Kejaksaan Tinggi Kalimantan Timur .

Langkah ini kemudian disambut dengan baik oleh semua stakeholder yang memiliki komitmen sama dalam memberantas tindak pidana korupsi di daerah Kalimantan Timur, baik lembaga penegak hukum, lembaga pemerintah dan non pemerintah serta lembaga-lembaga yang dibentuk berdasarkan peraturan perundang-undangan.

Tujuan yang diharapakan dalam kerjasama dan koordinasi ini ialah menutup jalur masuknya tindak pidana korupsi yang rawan berada di lembaga-lembaga pemerintahan, dan non pemerintahan. Kejaksaan Tinggi Kalimantan Timur kemudian menyusun bentuk-bentuk kerjasama dan koordinasi ini diantaranya berupa;

a. Korelasi yang besinergi dalam menyesuaikan pelaksanaan tugas pokok, dan fungsi yang telah disepakati antar instansi-instansi penegak hukum dalam kasus tindak pidana korupsi, seperti misalnya saling bertukar informasi berkenaan dengan proses penyidikan.

b. Membuat Memorandum of Understanding (MoU) dengan Aparat Pengawasan Internal Pemerintah (APIP) yang menegaskan mengenai koordinasi yang dilakukan antara Aparat Pengawasan Internal Pemerintah (APIP) dengan lembaga Kejaksaan khususnya Kejaksaan Tinggi Kalimantan Timur pada tahap penyelidikan suatu pengaduan masyarakat, dan tidak berlaku apabila tertangkap tangan (operasi tangkap tangan (OTT)), sehingga apabila aparat penegak hukum dalam menangani suatu laporan masyarakat dan kemudian setelah dilakukannya penyidikan, seseorang ditetapkan menjadi tersangka, maka tidak berlaku mekanisme koordinasi Aparat Pengawasan Internal Pemerintah (APIP) dan aparat penegak hukum.

c. Sosialisasi dengan pencegahan dan penanggulangan tindak pidana kepada pejabat negara, penyelenggara negara, lembaga non pemerintah, organisasi-organisasi diluar pemerintahan, serta elemen masyarakat lainnya.

Bentuk-bentuk kerjasama dan koordinasi tersebut diharapkan mampu mewujudkan peranan Kejaksaan Tinggi Kalimantan Timur dalam mencegah tindak pidana korupsi di Kalimantan Timur.

\section{Adanya Program Jaksa Masuk Desa (JMD), Jaksa Masuk Sekolah (JMS), dan Jaksa Masuk Pesantren (JMP)}

Program ini merupakan program terbaru yang dibentuk sebagai salah satu rangkaian pencegahan tindak pidana korupsi yang dilakukan oleh Kejaksaan Tinggi Kalimantan Timur. Terbentuknya program ini disesuaikan dengan fungsi pencegahan yang melekat didalamnya yaitu berkampanye atau bersosialisasi yang menjadi langkah strategis dalam memberantas tindak pidana korupsi.

Program Jaksa Masuk Desa (JMD), Jaksa Masuk Sekolah (JMS), dan Jaksa Masuk Pesantren (JMP) menuntut jaksa agar lebih berperan aktif di masyarakat melalui tahap pendekatan sebagai rangkaian pemberantasan tindak pidana korupsi, diantaranya; 
Jaksa Masuk Desa (JMD), ialah suatu program dalam mengawal dan memberi pendampingan hukum terhadap pembangunan-pembangunan di desa, agar tidak saling bersinggungan dengan kepentingan hukum.

Program Jaksa Masuk Desa (JMD), merupakan bentuk kooperatif lembaga Kejaksaan khususnya Kejaksaan Tinggi Kalimantan Timur dengan aparatur desa dalam menggunakan dan mengolah dana desa demi pembangunan desa yang bersih dari tindak pidana korupsi. Sifat pelaksanaannya sendiri berupa penyuluhan disetiap kabupaten atau desa.

Seperti diketahui bahwa daerah Kalimantan Timur, pada tahun 2018 menerima anggaran dana desa yang cukup besar untuk mendongkrak pembangunan desa di daerah Kalimantan Timur yaitu sebesar Rp. 730,92 Miliar. Oleh karenanya, agar realisasi dana desa tersebut dapat tercapai dengan optimal, maka diperlukan pengawalan dan pengawasan serta pendampingan hukum yang sifatnya penyuluhan dalam penggunaan anggaran desa yang diberikan melalui program Jaksa Masuk Desa (JMD) sebagai wujud peranan Kejaksaan Tinggi Kalimantan Timur dalam mencegah tindak pidana korupsi.

Target sasaran yang ingin dicapai oleh Kejaksaan Tinggi Kalimantan Timur melalui program Jaksa Masuk Desa (JMD) ini ialah memberikan pemahaman kepada aparatur desa yang lebih komprehensif mengenai pentingnya penyusunan perencanaan penggunaan dana desa hingga bentuk laporan pertanggungjawaban keuangan desa yang patut dipahami oleh aparatur desa.

Jaksa Masuk Sekolah (JMS), Jaksa Masuk Pesantren (JMP) ialah serangkaian program yang dilaksanakan oleh jaksa sebagai bentuk upaya pencegahan terjadinya tindak pidana korupsi yang berorientasi pada sekolah-sekolah, dan pesantren-pesantren.

Tujuan dilaksanakannya program Jaksa Masuk Sekolah (JMS), dan program Jaksa Masuk Pesantren (JMP) sederhana sekali, yaitu agar para pelajar sadar hukum sehingga melahirkan moral yang patuh pada hukum sejak dini dalam membentuk karakter anak bangsa yang berbasis hukum untuk ikut memberantas tindak pidana korupsi.

Bentuk kegiatan yang diberikan dalam program ini, berupa penerangan hukum yang diaplikasikan melalui penyuluhan hukum di sekolah-sekolah, dan pesantren-pesantren. Penerangan hukum ini diharapkan mampu menjadi sebuah proses pembentukan karakter anak bangsa dalam menumbuhkan moral bangsa yang tertanam pada jiwa anak bangsa berdasarkan nilainilai Pancasila sehingga kedepannya terbentuk anak bangsa yang berkarakter nasionalis dan anti korupsi.

\section{Menerima Pengaduan Masyarakat}

Elemen masyarakat merupakan pilar utama dalam mengawal pemberantasan tindak pidana korupsi. Dalam hal ini masyarakat menjadi pilar utama disebabkan karena masyarakat sangat dekat dengan keberadaan kejahatan itu. Kedekatan masyarakat ini disebabkan karena kejahatan tercipta akibat penyimpangan sosial yang terjadi di masyarakat, sehingga masyarakat tentu lebih mengetahui siapa dan kapan saja terjadinya tindak pidana korupsi.

Oleh karenanya, Kejaksaan Tinggi Kalimantan Timur memerlukan bantuan masyarakat dengan melibatkan masyarakat dalam mengawal pemberantasan tindak pidana korupsi di Kalimantan Timur. Keterlibatan masyarakat dalam hal ini yaitu ikut berperan aktif dalam mencegah terjadinya tindak pidana korupsi.

Dalam keterlibatan masyarakat ini, Kejaksaan Tinggi Kalimantan Timur memfasilitasi dengan memberi ruang kepada masyarakat melalui pengaduan masyarakat apabila diketahui ada indikasi tindak pidana korupsi yang kemudian disampaikan secara resmi berbentuk laporan kepada lembaga Kejaksaan khususnya Kejaksaan Tinggi Kalimantan Timur.

Setelah adanya laporan yang disampaikan kepada Kejaksaan Tinggi Kalimantan Timur, dan ditemukan adanya dugaan tindak pidana korupsi yang berdasarkan pengaduan masyarakat, maka Kejaksaan Tinggi Kalimantan Timur akan segera menindaklanjuti dengan melakukan 
surveilence dan apabila ditemukan indikasi Perbuatan Melawan Hukum maka Kejaksaan Tinggi Kalimantan Timur akan segera melakukan penyelidikan atau penyidikan dan penuntutan sebagai bagian dari upaya pemberantasan tindak pidana korupsi.

Tujuan dilaksanakannya program ini agar terciptanya kesadaran hukum yang minim ditengah masyarakat, sehingga agar terwujudnya pencegahan dalam memberantas tindak pidananya korupsi diperlukan kerjasama antara kedua elemen baik antara masyarakat maupun Kejaksaan Tinggi Kalimantan Timur. Untuk meningkatkan peran masyarakat tersebut, maka selain memberikan wadah, peranan Kejaksaan Tinggi Kalimantan Timur dalam hal ini ialah memberikan sosialisasi berupa penyuluhan hukum ke setiap elemen masyarakat di daerah Kalimantan Timur.

Adanya penerimaan pengaduan masyarakat merupakan salah satu upaya pencegahan yang diprakarsai oleh Kejaksaan Tinggi Kalimantan Timur, sehingga diharapkan mampu menimbulkan efek jera serta yang paling terpenting adanya asset recovery yang berimbas pada terhambatnya pertumbuhan tindak pidana korupsi.

Program-program tersebut merupakan upaya pencegahan tindak pidana korupsi yang menggambarkan Kejaksaan Tinggi Kalimantan Timur memiliki komitmen kuat dalam memberantas tindak pidana korupsi yang terjadi di Kalimantan Timur.

B. Kendala yang Dihadapi Kejaksaan Tinggi Kalimantan Timur Dalam Upaya Pencegahan Terjadinya Tindak Pidana Korupsi di Kalimantan Timur

Dalam mewujudkan upaya pencegahan tindak pidana korupsi, terdapat sejumlah kendala yang dihadapi oleh Kejaksaan Tinggi Kalimantan Timur, diantaranya;

Pertama, Rentang Jarak antara wilayah di Kalimantan Timur, adanya kondisi riil di lapangan yang sulit dijangkau oleh Kejaksaan Tinggi Kalimantan Timur dalam melaksanakan setiap program yang dicanangkan oleh Kejaksaan Tinggi Kalimantan Timur. Sulitnya penjangkauan wilayah di lapangan merupakan faktor utama bagi Kejaksaan Tinggi Kalimantan Timur dalam melaksanakan gagasangagasan upaya pencegahan tindak pidana korupsi di Kalimantan Timur.

Adanya kendala utama ini disebabkan karena luasnya wilayah Kalimantan Timur, yang mencakup banyak daerah-daerah pelosok yang sulit dijangkau di Kalimantan Timur, untuk dapat menerapkan semua program yang telah dicanangkan oleh Kejaksaan Tinggi Kalimantan Timur sebagai upaya pencegahan terjadinya tindak pidana korupsi.

Dampaknya, berakibat pada sulitnya penerimaan pengaduan masyarakat, padahal Kejaksaan Tinggi Kalimantan Timur berharap mampu mengakomodasi semua pengaduan masyarakat baik didaerah terpencil sekalipun, meskipun alternatif lainnya adalah masyarakat dapat mengadu ke Kejaksaan Negeri di daerah masingmasing, namun tetap tidak mampu mengakomodasi semua pengaduan masyarakat dikarenakan nyatanya dilapangan terdapat rentang jarak jauh antara tempat tinggal masyarakat dengan Kejaksaan Negeri di daerah masing-masing.

Ironinya, tindak pidana korupsi lebih banyak ditemukan di daerah-daerah dibandingkan di pusat atau kota. Ini terjadi karena Anggaran Pendapatan Belanja Daerah (APBD) atau dana bantuan lainnya seperti dana bantuan desa lebih banyak diterima dibandingkan di daerah pusat atau kota yang berimbas timbulnya tindak pidana korupsi besar-besaran yang dilakukan di pelosok-pelosok daerah Kalimantan Timur.

Kedua, Kondisi Geografis Kalimantan Timur, yang cukup luas dan sulit dijangkau menjadi rintangan tersendiri bagi Kejaksaan Tinggi Kalimantan Timur mengalami kesulitan yang cukup signifikan dalam menerapkan setiap program pencegahan tindak pidana korupsi. Kehadiran Kejaksaan Negeri yang menjadi representatif Kejaksaan Tinggi Kalimantan Timur belum mampu mengakomodir 
seluruh program pencegahan tindak pidana korupsi.

Oleh karenanya dalam mewujudkan program-program pencegahan tindak pidana korupsi seperti sosialisasi meningkatkan kesadaran hukum, penyuluhan hukum kesekolah dan pesantren serta koordinasi dengan stakeholder lainnya sulit untuk dilakukan.

Ketiga, Pola Pikir Dari Sebagian Masyarakat, Paradigma yang salah mengenai tindak pidana korupsi melekat ditengah masyarakat, khususnya di masyarakat pelosok daerah, ketika dipertanyakan tentang sejauh mana pemahaman mereka tentang tindak pidana korupsi yang melahirkan sebuah jawaban fenomenal bahwa tindak pidana korupsi adalah budaya.

Tidak dipungkiri, masyarakat memahami bahwa tindak pidana korupsi merupakan budaya Indonesia yang telah ada sejak zaman kolonial dan mengakar pada seluruh lapisan masyarakat, dan bahkan masyarakat menganggap bahwa tindak pidana korupsi merupakan sebuah timbal balik yang menguntungkan, bila menguntungkan rakyat, maka tidaklah masalah sehingga tidak perlu ada aduan masyarakat terhadap adanya tindak pidana korupsi. Ini terjadi karena masyarakat menggangap hal ini biasa terjadi ditengah masyarakat

Paradigma inilah yang harus segera diluruskan dan menjadi tanggung jawab bersama untuk memberikan pemahaman terkait tindak pidana korupsi bahwa apapun bentuk perbuatan tindak pidana korupsi tetap tidak boleh dilakukan karena berimbas pada jangka panjang bangsa kedepannya, sehingga kesadaran hukum masyarakat perlu ditingkatkan terhadap pemberantasan tindak pidana korupsi agar mampu memberikan kontribusi dalam upaya pencegahan tindak pidana korupsi.

Paradigma itu juga yang menjadi menjadi hambatan bagi Kejaksaan Tinggi Kalimantan Timur dalam melaksanakan upaya pencegahan tindak pidana korupsi di Kalimantan Timur, sehingga perlu penanganan mendalam terhadap pemberian pemahaman dalam meningkatkan kesadaran hukum masyarakat yang bukan hanya melakukan sosialisasi saja, namun juga lebih kepada rasa mengayomi yang diberikan oleh Kejaksaan Tinggi Kalimantan Timur apabila masyarakat berani berkontribusi untuk bertindak terhadap pencegahan tindak pidana korupsi di Kalimantan Timur.

Kendala-kendala tersebut diatas merupakan tantangan terbesar yang dihadapi Kejaksaan Tinggi Kalimantan Timur dalam menjalankan peranannya untuk mewujudkan upaya pencegahan tindak pidana korupsi di Kalimantan Timur.

\section{PENUTUP KESIMPULAN DAN SARAN}

Berdasarkan hasil pembahasan mengenai "Peranan Kejaksaan Tinggi Dalam Pencegahan Tindak Pidana Korupsi di Kalimantan Timur" maka dapat disimpulkan bahwa terdapat programprogram yang merupakan gagasan oleh Kejaksaan Tinggi Kalimantan Timur sebagai upaya pencegahan tindak pidana korupsi berupa membentuk Tim Pengawal dan Pengaman Pemerintahan dan Pembangunan Pusat (TP4P), dan Daerah (TP4D), pelaksanaan supervisi serta pemberian dukungan dan kerjasama serta koordinasi terhadap lembaga negara, lembaga pemerintah dan non pemerintah serta lembaga lainnya, program Jaksa Masuk Desa (JMD), Jaksa Masuk Sekolah (JMS), dan Jaksa Masuk Pesantren (JMP), serta menerima pengaduan masyarakat, merupakan bentuk peranan Kejaksaan Tinggi Kalimantan Timur sebagai komitmen memberantas tindak pidana korupsi sehingga mampu menekan pertumbuhan tindak pidana korupsi di Kalimantan Timur secara signifikan.

Disisi lain ditemukannya sejumlah kendala yg dihadapi oleh Kejaksaan Tinggi Kalimantan Timur dalam mewujudkan upaya pencegahan tindak pidana korupsi di Kalimantan Timur berupa rentang jarak antara wilayah di Kalimantan Timur, kondisi geografis dari Kalimantan Timur, pola pikir dari sebagian masyarakat, merupakan tantangan bagi Kejaksaan Tinggi Kalimantan Timur dalam 
mewujudkan upaya pencegahan tindak pidana korupsi di Kalimantan Timur.

Oleh karenanya penulis memiliki saran yaitu sebaiknya Kejaksaan Tinggi Kalimantan Timur lebih komunikatif dan intensif dengan besinergi antara semua stakeholder terkait dalam melaksanakan upaya-upaya pencegahan tindak pidana korupsi dalam rangka meningkatkan peranan Kejaksaan Tinggi Kalimantan Timur dalam memberantas tindak pidana korupsi.

Selain itu sebaiknya diperlukan kerjasama yang terjalin dengan berbagai lini bidang bukan hanya dalam hal penindakan tapi juga dalam hal pencegahan dengan berkolaborasi bersama-sama stakeholder lainnya sebagai bentuk upaya represif dalam mencegah tindak pidana korupsi di Kalimantan Timur.

\section{DAFTAR PUSTAKA}

\section{A. Buku}

Hamzah Andi, 2002, Hukum Acara Pidana Indonesia, Jakarta: Sinar Grafika.

Arief Barda Nawawi, 1998, "Kebijakan Legislatif Tentang Kewenangan Penyidikan Dalam Konteks Kebijakan Penegakan Hukum Pidana". Masalah-Masalah Hukum (Edisi I), FH UNDIP: Mei-Juni.

Muzaffar Chandra., 1986., "Wabah Korupsi " dalam Seri Wawasan Korupsi”., Jakarta: Lembaga Studi Pembangunan.

Darmono. 2013. Penyampingan Perkara Pidana (Seponering) Dalam penegakan Hukum, Jakarta : Solusi Publishing.

Hartanti Evi, 2008, Tindak Pidana Korupsi. Edisi Kedua, Jakarta: Sinar Grafika.

Danil Elwi., 2011., Korupsi Konsep, TIndak Pidana, dan Pemberantasannya., Jakarta: Raja Grafindo Persada.

Andrea Fockema, 1983., Kamus Hukum., Bandung: Bina Cipta Huruf C. Terjemahan Bina Cipta
Loqman Loebby, 1999, Masalah Tindak Pidana Korupsi di Indonesia. Jakarta: Badan Pembinaan Hukum Nasional Departemen Kehakiman dan Hak Asasi Manusia.

Mulyadi Lilik, 2000, Tindak Pidana Korupsi (Tinjauan khusus Terhadap Proses Penyidikan, Penuntutan, Peradilan Serta Upaya hukumnya Menurut Undang-Undang Nomor 31 Tahun 1999). Bandung: PT. Citra Aditya Bakti.

Poerwadarminta., 1976., Kamus Besar Bahasa Indonesia., Jakarta: Gramedia Pustaka Utama.

Alatas Syed Hussein., 1983., Sosiologi Korupsi: Sebuah Penjelajahan dengan Data Kontemporer., Jakarta: LP3ES.

Waluyo Bambang, 2002, Penelitian Hukum Dalam Praktek, Jakarta, Sinar Grafika. 


\section{B. Daftar Perundang-Undangan}

Undang-Undang Dasar Negara Republik Indonesia Tahun 1945

Undang-Undang Nomor 08 Tahun 1981 tentang Hukum Acara Pidana (KUHAP)

Undang-Undang No 31 tahun 1999 tentang Pemberantasan Tindak Pidana Korupsi sebagaimana telah diubah dengan Undang-Undang Nomor 20 Tahun 2001

Undang-Undang Nomor 30 Tahun 2002 tentang Komisi Pemberantasan Tindak Pidana Korupsi

Undang-Undang Nomor 26 Tahun 2000 tentang Pengadilan Hak Asasi Manusia.
C. Media Cetak

Kaltim Post.

Samarinda Post.

\section{Media Internet.}

Anonim. 2014. Komisi Pemberantasan Korupsi.

http://id.wikipedia.org/wiki/Komisi_Pem berantasan_Korupsi. Diakses pada tanggal 20 Februari 2014.

Anonim. 2014. Komisi Pemberantasan Korupsi.

http://www.kpk.go.id/id/faq. Diakses pada tanggal 20 Februari 2014. 